\title{
Kidney Epithelioid Angiomyolipoma
}

National Cancer Institute

\section{Source}

National Cancer Institute. Kidney Epithelioid Angiomyolipoma. NCI Thesaurus. Code C158032.

A rare variant of kidney ang iomyolipoma that consists of at least $80 \%$ epithelioid cells. (WHO 2016) 